Драгољуб Б. Ђорђевић, Ниш

\title{
АКАДЕМИК ИВАН ЦВИТКОВИЋ: ИСТАКНУТИ СОЦИОЛОГ РЕЛИГИЈЕ И ИСТИНСКИ ХУМАНИСТА
}

\author{
Човек је човек док има шта да каже \\ и док има ко да га чује, саслуша и разуме. \\ Миленко Пајић
}

Речи су стакло. Не треба гледати у стакло, него кроз юега, на свет Божји. Речи, као и стакло, постоје да би припуштале светлост.

Михаил Шишкин

\section{Приступ}

Имао сам големо задовољство да у више наврата пишем о “лику и делу” професора др Ивана Цвитковића, и то у периоду док још није сасма заслужено изабран за академика уважене Академије наука и умјетности Босне и Херцеговине.

Одмах откривам да смо пријатељи. То није утицало да у мојим анализама превлада субјективизам, таман посла “болећивост”, па да испадне како сам некритичан спрам њега - необјективан - већ га једино истичем и исписујем хвалоспеве. Наше другарство се одвија у складу с знаним Конфуцијевим [Confucius] изричајем: “Корисна пријатељства су пријатељства са исправним, искреним и људима великог знања."

Скрозирао сам академика Цвитковића кроз социолошко окно (Млади Петер Хандке [Handke] је “тврдио да речи нису прозорска окна кроз која се гледа, него да се помоћу њих ствари могу вртети, чиме се најбоље илуструје њихова друштвена улога", Делић 2019: 30). Ја већ годинама истражујем, не знајући за Хандкеову поетику, користећи скрози- 
рање кроз социолошко окно, што је поступак социолошког уживљавања или разумевања упакованог у својеврсни социолошки storytelling. ${ }^{1}$ Зато пођимо редом.

\section{Прва прилика}

Прва ми се прилика указала поткрај 1991. године када сам од Цвитковића примио примерак Рјечника религијских појмова (самостално издање). Већ сам био запањен чињеницом да ми у енциклопедистици и речничкој књижевности посвећеној религији каснимо недопустиво много наспрам Запада (Немачке, на пример) и Истока (бившег Совјетског Савеза, такође). Он је умешно испунио ту недопустиву празнину, моравши да Рјечник објави о "свом зноју и круху" и знајући за кључну тешкоћу: "Као основно, ни у једној од научних дисциплина које се баве проучавањем религије, па ни у социологији религије, не постоји цјеловито изграђена терминологија. То је захтијевало кориштење разне литературе, мада се и у њој, понекад, наилази на различита одређења истих појмова. У тим околностима ваљало је направити селекцију основних појмова, те, у неколико редака, дати њихова обиљежја, обичним језиком, разумљивим свима.” (Cvitković 1991: 3). Заобилазно хвалећи његов труд, питао сам се: 'Најпре, није ли то превелик терет који би пао на леђа појединца, социолога религије млађе генерације? Не упуштају ли се у ову врсту посла енциклопедијски настројени духови и то онда када накупе научно, стручно и животно искуство, по правилу на завршетку каријере? Затим, зар није то задатак групе аутора, тима интердисциплинарних стручњака, ако не и засебних института, одељења академија наука и других, одговарајућих научних асоцијација? За овакав подухват индивидуи је потребна најмање деценија прегалачког рада, а резултат до краја није известан! Напослетку, зар није логичније, интелектуално, научно и друштвено сврсисходније да овом послу приступе, на пример, Институт друштвених наука у Београду, Група за социологију Филозофског факултета у истом граду, САНУ, Богословски факултет Српске православне цркве...” (Ђорђевић 1991: 527). Како у уводним реченицама малкице споменух о објективности, старијем колеги и спочитах поводом осврта на положај тзв. Македонске православне цркве. ${ }^{2}$

\footnotetext{
${ }^{1}$ Тај поступак потцртавају српски социолози (Буквић 2019: 95): “У том погледу, професор Бранимир Стојковић с правом назива Брку (Д. Б. Ђорђевића - Д. Б. Ђ.) научником који је маестрално овладао умећем социолошког storytellinga."

2 “Будући да дуго година сарађујемо уз заједничко задовољство, надам се да следећа замерка, само налик политичкој, неће засметати. За похвалу је што Цвитковић адекватну 
То га није спречило, што говори о Ивановом интелектуалном поштењу и академским манирима, да ме узме за рецензента другог допуњеног и проширеног издања Рјечника (Cvitković 2005) и име ми задржи на трећем (Цвитковић 2009), које је истоветно претходном и које је изашло на ћирилици код угледне новосадске накладе “Прометеј” (препоручио га је Милан Шипка).

О одјеку и пријему српске верзије сведочи и податак да је Вукова задужбина организовала представљање у своме Дому, у строгом центру Београда. Такав догађај заслужује да овде пренесемо службену најаву:

"Поштовани,

После обимНог Посла на изради ВЕЛИКОГ РЕЧНИКА СТРАНИХ РЕЧИ И ИЗРАЗА академика Ивана Клајна и др Милана Шипке, и после лепог пријема те књиге у јавности, наставили смо са радом на лексикографским издањима и позивамо Вас на презентацију књиге

\title{
РЕЧНИК РЕЛИГИЈСКИХ ПОЈМОВА \\ угледног сарајевског професора др Ивана Цвитковића
}

\author{
Учествују: \\ - $\quad$ проф. др ИВАН ЦВИТКОВИЋ \\ - $\quad$ проф. др МИЛАН ШИПКА \\ - $\quad$ проф. др ДРАГОљУБ Б. ЂОРЪЕВИЋ \\ - ЗОРАН КОЛУНЏИЈА
}

ВУКОВА ЗАДУЖБИНА, Београд, петак, 27. март у 12,00 часова

\section{О Речнику:}

Развојем филозофије, историје, психологије, политологије, журналистике, а посебно социологије религије, јавила се потреба и за речником религијских појмова.

Отуд идеја да се у овом речнику обраде карактеристични појмови из различитих религија: староегипатских, старогрчких, старословенских, старогерманских, хиндуизма, будизма, конфучијанства, таоизма, ламаизма, шинтоизма, јеврејске религије, ислама, католичанства, православља, протестантских секти, ромских и афричких веровања итд.

пажњу посвећује Македонској православној цркви. То се очекује од једног лаичког социолога религије, али такође и чињенична информација да ова црква није 'призната', односно међу православним црквама нема статус аутокефалности, помесности, чак ни положај аутономне цркве, попут Јапанске и Финске.” (Ђорђевић 1991: 528). 
Можда ће се неко запитати зашто су у речник религијских појмова уврштени и они из домена празноверја, магије. Одмах да кажемо: не само због теоријских противречности о односу магије и религије већ и из практичних потреба.

Овакав речник није никад био тако потребан као данас кад поново расте заинтересованост за религију. Очекујемо да ће он добро доћи свима у мултиконфесионалном друштву да би се, на најлакши могући начин, упознали с основним појмовима из религија својих суграђана.

Ово издање урађено је према сарајевском допуњеном и проширеном издању из 2005. године, адаптирано је за српски језички израз у сарадњи са аутором, има непуних 500 страница речничког формата и обухвата 8900 појмова."

Узгред, сем Рјечника, рецензирао сам ниску Цвитковићевих књига монографија и студија - међу којима ми је посебно била част што сам потписао следеће: Социологија религије (2004a, 2007a), Социјална научавања о религијама (2007b), Религија у зриалу теорија (2016), Религија у раљама политике (2019).

\section{Друга прилика}

Други пут, негде средином првог десетлећа трећег хиљадугодишта, знатно исцрпније представио сам лик и дело професора Цвитковића, његов животни, професионални и академски друм, уврстивши га у десет најзначајнијих југословенских социолога религије. Ранији вид есеја, прецизније социолошке скице, под насловом “Скица за портрет YU coциолога религије: Иван Цвитковић (1945-) - социолог религије свестраног видика" објавио сам 2007. у Годишњаку за социологију (Ђорђевић 2007: 17-28), журналу Филозофског факултета Универзитета у Нишу, а каснију варијанту под именом “Иван Цвитковић” у књижици Узорници и пријани: скице за портрет YU социолога религије (Ђорђевић 2008: 103-112). Напису, смотрено с дванаестогодишње удаљености, ама баш немам ништа да додам и одузмем! Слободан сам стога да га у целости сада пренесем:

\section{“Иван Цвитковић}

Служба

Иван Цвитковић, тај наочити Херцеговац, рођен 1945. године у Мостару, имао је типичну професионалну каријеру за своју добну скупину ондашње Југославије. Завршио је 1967. године социологију на сарајевском Факултету политичких наука, магистрирао 1974. на истоименом 
загребачком факултету и последипломском студију Теорије атеизма и религије - тема: "Католичка црква и омладина у урбаним срединама Босне” - и докторирао социологију религије 1978. на љубљанском Факултету за социологију, новинарство и друштвене науке (радња: “Марксистичка мисао и религија (критика теолошке критике односа марксизма и социјализма према религији)"3). Продужавајући и скраћивајући изборно наставничко време, прошао је једнолинијску универзитетску каријеру, почев од асистента 1972, преко доцента 1980. и ванредног професора 1986, до редовног професора 1989. на предметима Социологија религије и Социологије сазнања и морала на Катедри за социологију Факултета политичких наука у Сарајеву. Још је предавао Општу социологију (Грађевински факултет) и Социологију села (Агрономски факултет) на Свеучилишту у Мостару, као и Филозофију и културу монотеистичких религија на Филозофском факултету у Тузли.

Био је члан уредништва часописа: Лица, Породица и дијете, Опредјељења, Етос - сви из Сарајева - а данас редакције журнала Религија и толеранција (Н. Сад). Сада је члан Управе Удружења за политологију БиХ и "редовити члан Хрватског друштва за знаност и умјетност (Сарајево)".

За разлику од множине истоврсника, који се свим силама труде да обавију мраком свој живот у социјалистичком периоду, заташкају чланство у Савезу комуниста Југославије (СКЈ) и прикрију освајане позиције у апарату власти - које су мањини доносиле знатне привилегије - проф. Цвитковић, за кога поуздано знам да се тиме баш није окористио, без икакве ограде и забашуривања такве податке наводи у биографији: "Радио у руководству Савеза социјалистичке омладине 1967-1971. Обављао дужност директора Марксистичког студијског центра 1979-1982. Био извршни секретар Предсједништва ЦК СКБиХ 1982-1986; члан Предсједништва ЦК СКБиХ 1986-1988 и секретар истоименог тијела 19881989. год." У Институту за проучавање националних односа, тада јединственом у свој земљи, делао 1989-1990. године.

Подразумева се да тако покретљив и угледан социолог религије, што је Цвитковић неспорно, буде изванредно стручно и предавачки активан, учесник бројних светских и домаћих научних симпозијума и наставник на разноликим додипломским и магистарским школама (Свеучилиште у Загребу, Филозофски факултет, постдипломски студиј Теорија атеизма и религије, 1985; магистарске студије на Свеучилишту у Сарајеву, социологија, 1996, 1997, 1998, 2001, 2005, 2006; последипломске студије у

\footnotetext{
${ }^{3}$ Теза укоричена у књигу и штампана (Cvitković 1980b).
} 
Београду, БОШ и ААОМ, 2001, 2002; и последипломске студије на Факултету исламских наука, Сарајево, 2006. године). ${ }^{4}$

Изгледа да се његова делатност у академском смислу - као професора социологије религије - после заморних преговора, најзад врхуни оснивањем Магистарског програма из области религијских студија на којем ће руководити предметом Религије света (Центар за интердисциплинарне постдипломске студије /ЦИПС/ Универзитета у Сарајеву у сарадњи са Државним универзитетом Аризоне - Одељење за религијске студије /САД/ и Универзитетом у Ослу - Одељење за културалне студије и оријенталне језике /Норвешка/). ${ }^{5}$ Студенти ће стицати академско звање магистар религијских студија - енглеска верзија: M.A. in Religious Studies.

\section{Познанство}

Порано, још у предрадњама за докторску тезу, запазио сам првотне Иванове религиолошке текстове и публикације. Носећи се мишљу да искуствено истражим утицај урбанизације на процес секуларизације и атеизације младих мога краја, нисам могао а да не набасам на штампане делове његове магистарске радње о религиозности католичке младежи босанских урбаних средишта, издат докторат и, подвлачим, есеј “Партиципација у религијским активностима”, објављен у Биљешкама о религији (Cvitković 1980a: 67-74), првој од њега купљеној књизи. Како онда да нисам жудео за познанством с др Цвитковићем?

То се ненадано збило на великом скупу о теми Савез комуниста и религија, одржаном 1984. год. у Кумровцу у просторијама Политичке школе “Јосип Броз Тито”, ондашњој “икони” Савеза комуниста Југославије. ${ }^{6}$ У друштву неколицине религиолога, сусрет се убрзано претворио, ни овога трена не могу да се отмем том утиску, у пријатељевање које још увек траје и богати се.

\footnotetext{
${ }^{4}$ Менторисао је ниску докторских и магистарских радњи. Издвајам докторат мр Петра Ћебића Екуменизам и вјерска толеранција у Југославији, касније примећен као књига, и магистратуру асистента му Дина Абазовића о религијском национализму.

${ }^{5}$ Студијски предмети су занимљиви: Религије свијета, Ритуал, симбол и мит, Религија и род, Религија, насиље и решавање конфликта, Западне религијске традиције, Класична исламска мисао, Религија и национализам у југоисточној Европи, Религија и људска права, Религија и кинематографија: истраживања у популарној култури, Савремене религијске теорије, Христологија од периода просветитељства, Религија и образовање, Религија и социјална правда, Компаративно религијско право. Мени ту фали социологија религије као засебна дисциплина.

${ }^{6}$ Материјал објављен у Кумровечким записима 2/1984.
} 
У два маха, пре распада земље, није дошло до гледања - једном због моје, а други пут његове “кривице”. Најпре, лењост ме спречила да 1985. одлетим у Сарајево и присуствујем великом скупу О односу националног и религијског на селу (мој реферат и прилог "Национално и религијско на селу”, Ђорђевић 1985: 216-220), на његов позив и у организацији Института за проучавање националних односа. Затим, случајност је кумовала да се не сретнемо у Сарајеву - беше ли јануара или фебруара 1992. године - у цик босанско-херцеговачког сукоба. Тамо сам боравио с екипом ${ }^{7}$ нишких социолога два-три дана на јавном снимању култне научне емисије ТВ Сарајево "Поинт", а на позив цењеног журналисте мр Младена Суботића (ратна га пошаст преселила у Скандинавију). У прелепом амбијенту Француског културног центра, неколико сати жустро смо расправљали с босанским постмодернистима у успону - др Сулејманом Бостом и мр Југославом Влаисављевићем, ${ }^{8}$ онда доцентом и асистентом Филозофског факултета - на тему, гле ироније, "Чему још социологија?”, тј. односа социологије и постмодерног друштва. Нонстоп сам телефонирао Цвитковићу, али авај - некуда је одлутао.

Ипак смо се у међувремену видели и незаборавно дружили у Новом Саду, године $1989 .{ }^{9}$ А онда, проклет био, пукну страшан рат мржње и насиља!

\section{Рукописна сарадња}

Са др Цвитковићем, као ни са ким другим социологом религије из бивше “Југе”, имам деценијску и плодну рукописну сарадњу. Отпочела је давне 1986. године објављивањем текста "Читање традиције: верска штампа и њен однос према културној и религијској свести у нас" (Цвитковић 1986а: 105-109), наставила се 90-их - "Развијати социологију религије” (Цвитковић 1991б: 217-224); “" “Православни међу католицима

\footnotetext{
${ }^{7}$ Састављеном од др Драгана Жунића, редовног професора Факултета уметности у Нишу, тада у звању ванредног на Филозофском факултету, мр Ђокице Јовановића, онда главног уредника нишке Градине, а данас ванредног професора Филозофског факултета у Београду, и мр Ненада Поповића, још и сада асистента Филозофског факултета у Нишу.

${ }^{8} \mathrm{O}$ том талентованом босанском Србину, који је остао у Сарајеву, ништа нисам чуо скоро деценију и по, да бих га овог лета препознао на страницама НИН-а (26. 7. 2007, стр. 39-41), но сада као - Уга Влаисављевића. Филозоф и писац интригантне књиге Лепоглава и универзитет (2003) прекрстио је име.

${ }^{9}$ Подробније описано у делу о Марку Кершевану.

${ }^{10}$ Штампано поводом моје књиге О религији и атеизму. О књизи и уз њу, у темату Религија и атеизам, писали су још Јаков Јукић, Никола Скледар, Марко Кершеван,
} 
и припадницима ислама у Босни и Херцеговини” (Цвитковић 1991в: 327-346) - и распламсала у трећем миленијуму. Скицу би оптеретило навођење свих радова које сам му публиковао у ЈУНИР годишњаку и зборницима произашлим из научних пројеката са Филозофског факултета у Нишу, али жеља ми је да истакнем два најновија: први јесте есеј “Муке са светим на примјеру данских карикатура", по позиву поштено написан за моју последњу књигу Муке са светим (Ђорђевић 2007б, 185 195), а други, наиме, чине одреднице које је, опет на моју молбу, спремио за Социолошки речник (2007).

Неоспорно је да се Иван увек одазивао на кооперацију, за шта сам му захвалан, но, не страхујући за последице, изричем истину о томе да је досадашња сарадња ишла само у једном правцу: рукописи су путовали од Сарајева к Нишу - ретко, односно никада у обрнутом смеру. Хоћу да верујем да су томе “кумовале” моје уредничке позиције, приређивачке склоности и наглашене организационе активности. (Ето како бих згрешио душу, јер ми, баш кад заврших “Скицу”, Ива пише у мејлу од 9. јула 2007: “Коначно смо договорили с Американцима за постдипломске студије из области религије. Погледај о томе на www.cps.edu.ba. Види предмет који ћу ја водити /о религијама сувременог свијета/ и одабери тему која би Ти одговарала. Волио бих да гостујеш на том студију. О детаљима има времена да се договоримо. Јави се, прије него што одеш на одмор. Поздрав од Цвитковића.”)

\section{Књига миљеница}

То је Рјечник религијских појмова (Cvitković 1991). А зашто да не буде Марксистичка мисао и религија (Cvitković 1980b), сећајући се доба “када смо сви били марксисти”; онда, доиста међу бољим нашим уџбеницима, Социологија религије (Cvitković 1995; три издања), чији сам рецензент био 2004; или Конфесија у рату, за коју је добио награду Факултета политичких наука као за најбољу књигу у 2004. г. и о којој сам на ASN Conference Globalization, Nationalism and Ethnic Conflicts in the Balkans and its Regional Context (Београд, септембар 2006) беседио као о најпоштенијем рукопису о босанском рату; па и Друштвена мисао у светим списима (Cvitković 1997), корисна социолозима религије који, насупрот богословима и историчарима религије, нису тако директно на њих упућени?

Синиша Зриншчак, Мирољуб Јевтић, Јири Свитек и Мирко Благојевић. 
Но на Рјечник типујем из два разлога: емотивног и религиолошког ни малкице због тога што сам рецензирао издање из 2005. - и недавно сам их описао (Гавриловић - Ђорђевић, 2005: 16): “Када се 1991. године појавило прво издање 'Рјечника', ја сам у часопису Nissa, који је тада излазио у Нишу под мојим руководством, написао критички приказ. Од ставова изнесених у том приказу ни данас не одустајем: био је то редак подухват, када на простору читаве тадашње Југославије ми нисмо имали таквих дела. Била је штампана књига Религије свијета у Загребу и тек се појавила Енщиклопедија живих религија код 'Нолита'. Али, и са постојањем тих књига наши су аутори морали да дописују одреднице везане за православље, па и за православље на Балкану, а и ислам је био доста занемарен. Коректности ради, треба споменути од стране православног аутора Чедомира Драшковића и скроман Теолошки речник. Иако књига проф. Цвитковића није енциклопедијског карактера, већ у правом смислу речник са бројним, а кратким, лексикографским одређењима, она се појавила, како видимо, у право време. Врло је важно да се и тада и сада појављује у једном мултиконфесионалном друштву као што је Босна и Херцеговина, да је Цвитковић равноправно, колико је то било могуће, поделио одреднице које припадају трима признатим религијама и конфесијама на овом простору: исламу, католичанству и православљу. Отишао је и корак даље, па је један број одредница посветио и осталим откривеним светским религијама и другим мањим верама, доприневши тако исцрпности свог речника. Стога претпостављам да ће се врло брзо распродати и ово издање и да ће морати да уследи и треће.”

\section{Домет}

Иван је Цвитковић социолог религије свестраног увида. Има ли међу социолозима религије плоднијег делатника? Не, ради ли се о ауторским књигама - написао их је прегршт - или ако су у питању приређени зборници и чланци у часописима и зборницима текстова. ${ }^{11}$ Додуше, ту улази и многи репринт, ${ }^{12}$ што неумољиво сведочи о њему као радо читаном писцу и утицајном ствараоцу. Да ли је међу нама неко ко се као Цвитковић посвећивао тако разноврсним темама? Нема таквог, спомену ли се само неколике проблемске области. Јер, међу другим, он је дубоко про-

\footnotetext{
${ }^{11}$ На web страници АНУБиХ, код наслова “Редовни чланови” и уз његово име, могу се наћи сви подаци о до сада објављеним књигама.

${ }^{12}$ СКЈ и религија $(1982,1985)$, Тко је био А. Степинац (два издања 1986b), Религија: питања и одговори $(1983,1986)$, Рјечник религијских појмова $(1991,2005)$, Социологија религије $(1995,1996,2004)$ и Религије сувременог свијета $(1999,2002,2005 a)$.
} 
учавао: конкретне личности - Мирослава Крлежу и Алојзија Степинца - и те како важне у култури једног народа и његовог односа према иним народима и њиховим религијама и вероисповестима; монополистичку политичку странку - Савез комуниста Југославије - и те колико пресудну за положај религије у бившој нам држави; преовлађујући светоназор - марксизам - стављен у идеолошку основицу свег друштва, тиме и у темеље односа према вери; религијску панораму - верске заједнице у БиХ - без чијег је непосредног познавања мањкав сваки напис о религијско-црквеном комплексу; класичну религиозност - религијску свест и религијско понашање и удруживање - што је “домаћи” задатак сваког социолога религије; друштвеност религија - друштвену мисао у светим списима - да би се подсетило на то за шта су оне уопште ту; системе религија света - њихово устројство и наук - да се установе сличности и разлике; вероисповедну позадину сукоба - рат у БиХ - која је несумњиво постојала; национални идентитет свога народа - на случају босанских Хрвата - у којег религија јесте јак градивни елеменат... и пуно тога још.

Искреније срочено: о чему ма није проф. др Иван Цвитковић писао, и може ли му се по тој издашности неко макар приближити!? Зар није по много чему трајно задужио нашу дисциплину. - И због тога је, без двојбе, већ дуго времена најбољи босанско-херцеговачки социолог религије, знан и цењен диљем Балкана. ${ }^{13}$

\section{Одважан човек}

Ранији југословенски оријентисан омладински руководилац и политички делатник - одувек комуниста и отворени марксиста - не одустајући од годинама гајеног вредносног склопа, показао се одважним човеком у предратном, ратном и поратном босанском периоду. Отворено радећи на сузбијању конфликта, одбио је да му се прикључи када је прокључао - јер то није био “његов” рат - прилично рескирао за време борбених дешавања и високоморално дочекао мир. Оставши у Сарајеву, и у “миру” приноси миру као редак интелектуалац од величине који, залажући се за вишеконфесионалну Босну, упорно промовише мултикултурализам и интеркултурализам, верски дијалог, толеранцију и екуменизам. Није без идентитета и ентитета, али му не сплашњава - многи једва чекају - критички став према слабостима своје нације и вероисповести.

\footnotetext{
${ }^{13}$ Изабрао је за наследника Д. Абазовића, талентованог помоћника, који, усаврши ли се како треба, има шансе да настави његово дело.
} 
E, такав Цвитковић, неомиљен код националних душебрижника, ратних профитера и сатрапа свакојаких фела, јесте радо примљен у социолошком братству. Стасит и пријатан, шармер и вицкаст, џентлмен и сусретљив, умерен у “ићу и пићу” - он свако окупљање преиначи у дружење за незаборав. Што не обелоданити - и женама се допада.

И лична нота: као млађани социолог религије на време сам упознао и препознао проф. Ивана Цвитковића, отпрве прихватио колегу од кога ce да̂ доста тога научити - дакако, и о животу уопште - да не помињем несрећни рат, за чијег трајања смо непрестано били у посредном контакту, изналазећи неуобичајене и тајновите канале и пречице да дотуримо један другом новоизашлу социолошку књижевност из Хрватске и Босне и Херцеговине, односно Србије. Пресрећан сам што имам за пријатеља тако драгу особу.

\section{Последње виђење}

Босанска трагедија је прекинула непосредну комуникацију и она се за то време одвијала преко заједничких познаника. ${ }^{14}$ Тек што је утихнуло оружје, одмах смо се видели у “вилином граду” (1997. и 1998), да би се предивни сусрети умножили. Бирам три.

Два пута смо гостовали у Словенији, дакле - за обојицу сада у иностранству. Једном, 1998, захваљујући пажњи др Флереа, који је на Правном факултету Универзитета у Марибору успео да окупи завидан број социолога религије из свих бивших југословенских република на тродневној конференцији о стању и перспективи конфесионалне веронауке у јавном школству. Четири епизоде су ми урезане у памћење: Цвитковићево објективно представљање ситуације око инсистирања, притиска чак, да Срби, Хрвати и Бошњаци понаособ уведу и контролишу најобичнију верску поуку, чисто конфесионално постављену - православну, римокатоличку, исламску - која не би марила за ину, ону комшијску религију или вероисповест, камоли за неку тамо удаљену верску праксу, и става ретких интелектуалаца да се инсталира религијска култура или култура религија, као нешто што је далеко примереније босанским приликама; наступ доц. др Синише Зриншчака ${ }^{15}$ о положају и резултатима конфесионалног вероучења у Хрватској, који је, иако поткрепљен

\footnotetext{
14 У одељку пишем о “последњем виђењу” у смислу последњих сусрета пре завршне верзије "Скице”, а не тако као да их уопште више неће бити.

${ }^{15}$ Срећан сам био и због виђења са млађим пријатељом, који је у међувремену изузетно напредовао и данас је најпознатији хрватски социолог религије у међународним сразмерама.
} 
подацима и мајсторски изведен, очито “навијао” у правцу: црквено поучавање школске деце и младежи јесте “најзад пронађена мудрост”, док су судионици очекивали и некоју критичку опаску од социолога религије таквог формата; моја интервенција на тираду господина Радована Дамјановића, ${ }^{16}$ црногорског делегата, којом је без трунке повода “осуо паљбу" на Србију и Српску православну цркву јер тлаче браћу и не дозвољавају јој да развије верске могућности; и до касно у ноћ вансимпозијске седељке с проф. Цвитковићем и проф. Петрем Георгиевским, водећим македонским социологом.

Наредног смо наврата, од 23. до 25. фебруара 2001, походили Блед на позив др Силва Деветка, професора Правног факултета у Марибору, и присуствовали међународној конференцији Демократија, људска права и заштита припадника етничких и верских мањина у Југоисточној Европи. (Тако огромне скупове ${ }^{17}$ - од Рогашке Слатине и Бледа, преко Београда и Скопља, па све до егзотичног Кишињева /Молдавија/ - а на свим сам учествовао, могао је да организује, и да за њих приволи људе с још свежим “ратним ранама", једино др Деветак, човек невероватне снаге и ентузијазма.) Бити за Цвитковићевим столом у ексклузивном бледском хотелу изистинско је задовољство, размењивати наставничко и професионално искуство социолога религије и већи је ћар, “ “тројку”18 расправљати оно што нас скупа чека на стази јединственог европског образовног простора јесте најголемији добитак.

Обезбедио сам трећу згоду, тј. радни сусрет на XV спрату Београђанке, 4. јуна 2001, понудом да одржи предавање “Улога религија и конфесија у предратно, ратно и поратно време у Босни и Херцеговини” на последипломском курсу Религија: тачка културног спајања или раздвајања?, који сам осмислио и водио ${ }^{19}$ за онда чувени ААОМ (Алтернативна академска

\footnotetext{
16 Добро сам проценио ситног каријеристу - отад је увек “нешто” у тамошњем министарству образовања - који оптуживањем Срба и Србије добија поене за опстанак у номенклатури.

${ }^{17}$ Конференцији је присуствовало више од 150 стручњака, активиста покрета за људска права и мировних покрета, чланова мањинских група, великодостојника из свих већих верских заједница, службеника и владиних званичника из земаља Југоисточне Европе, а такође и представника заинтересованих међународних владиних и невладиних организација.

${ }^{18}$ Придруживао се амерички колега Џејмс X. Сетервајт (Satterwhite), припадник квекерске заједнице, професор на Блафтон универзитету, који нас је добрано уздрмао страхом за намештење - приближавало му се време избора предмета, а студенти се не морају одлучити за његове.

${ }^{19} \mathrm{У}$ томе ми је зналачки помагала Маријана Филиповић, изненађујуће спремна - a млада - особа; била асистент на Филозофском факултету у Косовској Митровици, да би
} 
образовна мрежа). Иван је, нашавши се у сјајном друштву гостујућих наставника - академика Владете Јеротића, проф. др Ђуре Шушњића, проф. др Радише Антића, др Андрије Копиловића и ефендије Хамдије Јусуфспахића - добио највише оцене магистраната. Да ли сам сумњао у такав исход? Ни у сну, знајући Цвитковићеве предавачке квалитете.

Све у свему, са Ивом се гледам бар годишње на конференцијама - до сада их је 14 одржано ${ }^{20}$ - Југословенског удружења за научно истраживање религије (ЈУНИР), чији сам оснивач и први председник, и које сам до летос директно усмеравао. ${ }^{21}$ Он јесте од социолога религије са негдашњег југословенског простора најревноснији сарадник ЈУНИР-а и редован учесник његових скупова. ${ }^{22}$ (То ценећи, као и шездесет година живота и рада, Удружење му је 2005, на XII конференцији у Сирогојну, приредило скроман омаж и промовисало друго издање Рјечника религијских појмова. ${ }^{23}$ ) С узбуђењем сам очекивао сваки Иванов наредни долазак - било их је редовно све до 2017, чему се радовао и многи нишки социолог.

\section{Цвитковићева искрица за социологе религије}

“Социолог код религије истражује оно што је доступно искуственој евиденцији. Тако он не може изучавати виле, вјештице, духове јер не

прошлог лета напустила земљу и отишла да гради каријеру у Уједињеном Краљевству. - Тиме штети ионако кадровски угрожена српска социологија религије.

${ }^{20}$ Ред је да се и остали социолози религије упознају бар с њиховим насловима: Религија - рат - мир, 1994; Религија и развој, 1995; Религија - црква - нација, 1996; Етнорелигијски односи на Балкану, 1997; Веровања, организација и деловање религијских заједница и покрета, 1998; Хришћанство - друштво - политика, 1999; Две хиљаде година хришћанства на Балкану, 2000; Вере мањина и мањинске вере, 2001; Културни и етнички идентитети у процесу глобализације и регионализације Балкана, 2002; Религијска култура Рома, 2003; Мисионарење, преобраћање, прозелитизам, 2004; Религија и глобализација, 2005; Протестантизам на Балкану, 2006. и Ислам на Балкану, 2007.

${ }^{21}$ Сва је прилика да ћу бригу о њему пренети на Драгана Тодоровића, далеко млађег и све предузимљивијег нишког социолога религије, јер је већ доказао да зна водити рачуна и о општем социолошком добру.

${ }^{22}$ Вреди пописати Цвитковићеве реферате: "Нација и конфесија у рату (на примјеру рата у БиХ 1991-1955)” (1997: 45-56); “Однос религијских учења према народу-нацији (социолошки модел)”; (2001: 62-66); “Однос између националног и конфесионалног идентитета" (2002: 123-126); "Notes on Romas' Religious Beliefs" (2003: 27-30); "Relations Between Christians and Muslims (The Case of Balkans)" (2004v: 33-39); "Theme: Religion and Globalization" (2005b: 17-25); "The Relationship of 'Historical Based' Religious Communities Towards Protestant Communities” (2006: 51-59).

${ }^{23}$ Сем њега и мене, говорили су још Д. Гавриловић и М. Млакар (Гавриловић Ђорђевић 2005: 15-19). 
може утврдити индикаторе уз помоћ којих би се емпиријски утврдило постоје ли оне или не постоје. Он неће истраживати (не)истинитости религијског учења. Да ли је католичко, исламско, православно и сл. учење (не)истинито - то није предмет социолошког проучавања. Социолог се, такођер, неће упуштати у то да ли је ислам боља религија од кршћанства или обратно: да ли је кршћанство боља религија од ислама. Без обзира на лични однос социолога према религији, он не може, у свом социолошком раду, вршити напад на религију.”

Животопис доктора Цвитковића, удружен с цртицама о иним социолозима религије, изазвао је одговарајућу позорност. Дотле, да покоји социолог моју работу проглашава малом историјом нашинске социологије религије. Тако, примерице, Драган Тодоровић (2019: 14) за потребе споменичарске књиге о мојој маленкости пита ме и устврђује: “Но, ту није крај! Написали сте и занимљиву а кратку, неко би тако формулисао, историју југословенске социологије религије. Имам у виду Вашу књигу Узорници и пријани: скице за портрет YU социолога религије.” Док му ја отправљам следећи коментар: “Њоме се истински гордим и, без лажне скромности, тек ће се сагледати њен значај. Дозволио сам себи да, надам се према објективним мерилима, одаберем десет најзначајнијих југословенских социолога религије, који су деловали од средине 60-их минулог века до тренутка писања студије (2007) и критички обрадим њихов живот и дело. У мој избор су ушли: Штефица Бахтијаревић, Срђан Врцан, Никола Дуганџија, Јаков Јукић, Марко Кершеван, Никола Скледар, Есад Ћимић, Сергеј Флере, Иван Цвитковић и Ђуро Шушњић. Нажалост, професори С. Врцан и Н. Скледар, као ни доктор Ј. Јукић (Жељко Мардешић), нису дочекали да виде како сам их 'сместио' у историју социологије религије негдашње нам домовине. Ради примера и истине, одговорно тврдим да се у Хрватској после толико година још није 'родио’ тзв. лаички социолог религије попут С. Врцана, европски цењеног стручњака, или тзв. религијски социолог религије као што је то био Ј. Јукић, такође европски познати религиолог. Поједини су у међувремену напредовали: И. Цвитковић је редовни члан АНУБиХ, проф. емеритус С. Флере, понављам - мој ментор на докторату, постао је вероватно најпознатији социолог религије у светским сразмерама са ових простора, а о проф. Ђ. Шушњићу да не трошим реч. Са некима од њих сам пријатељ, поједини су ми помогли у право време, док с инима одржавам и даље 
људске и професионалне контакте. Да ли сам им се достојно реванширао - судиће време (Тодоровић 2019: 14-15)?!'24

\section{Трећа прилика}

Најпосле сам, добивши понуду да срочим предговор за његову књигу на енглеском, махом понављајући већ изречено у горепоменутим чланцима и књизи, убележио зашто му баш тог лета Југословенско удружење за научно истраживање религије објављује Encountering Others (Cvitković 2013), подвукао још једну у међувремену примећену особину - полемичност - и усудио да изнесем сводну оцену Ивановог лика и дела (Đorđević 2013). Тако сам те године, у предговору "Encountering Others - Academician Ivan Cvitković, Sociologist of Religion and Humanist" (Ђopђевић 2013: vii-viii), забележио да су три “крупна повода зашто Jyгословенско удружење за научно истраживање религије (YSSSR), чије је седиште у Нишу (Србија), издаје зборник текстова на енглеском језику др Ивана Цвитковића, редовног професора социологије религије на Факултету политичких наука у Сарајеву (БиХ):

1. Споменуто Удружење 2013. слави јубилеј: двадесет година како редовно организује годишње YSSSR конференције с међународним учешћем, на којима су учествовали виђенији балкански, који пут и европски и светски, социолози религије, као што су, примера ради, Ајлин Баркер (Barker), Сергеј Флере, Синиша Зриншчак, Нонка Богомилова, Алексиос Панагопоулос (Panagopoulos), Ружица Цацаноска, Џон Стивенсон (Stivenson), Дарко Танасковић, Јулија Синелина. Међу њима посебно место припада професору Цвитковићу.

2. Професор Цвитковић је све то време био најредовнији страни учесник YSSSR конференција. На 12 њих, од укупно двадесет, држао је веома запажене реферате и изазивао плодне расправе. Његов допринос YSSSR је напросто немерљив: Удружење је расло и развијало се уз његову несебичну научну, стручну и колегијалну подршку. Али, бићу отворен, и YSSSR је допринело подизању и ширењу Цвитковићевог научног угледа на балканском и европском простору, добрано промовисало његове резултате у социологији религије. Делом и због тога - надам се да не претерујем - он је

\footnotetext{
${ }^{24}$ Још 2008. године пресудио је Синиша Зриншчак, данас интернационално најпробитачнији хрватски социолог религије, у предговору “Пледоаје за социологију религије - скица за разговор” (Ђорђевић 2008: 9-14).
} 
2008. изабран за дописног члана АНУБиХ, а у децембру 2012. и за редовног члана. ${ }^{25}$ Иван Цвитковић је до сада једини социолог религије из бивших југословенских република изабран за академика државне академије, што се на дотичном простору веома цени и поштује.

3. У читавој 2013, у хришћанском свету, слави се велики јубилеј: 1700 година од проглашења Миланског едикта. ${ }^{26}$ Читаоци ће, само из овде сакупљених текстова, видети да Цвитковић, у најсуштаственијем значењу тога појма, баштини кључне идеје Едикта. Он је пример социолога религије који се залаже за мир и толеранцију, дијалог и екуменизам, што и није изненађење за научника који је цео свој животни и радни век провео на трусном подручју Босне и Херцеговине, земље у којој се сусрећу две откривене религије - хришћанство и ислам - и где се преплићу две хришћанске конфесије: православље и католичанство. Професор Цвитковић и искуствено сведочи о томе шта то значи кад, због изостанка дијалога, толеранције и екуменизма, религије, вероисповести и религијске институције буду инструментализоване и увучене - при чему њихова кривица није мала ${ }^{27}$ - у страшан рат мржње и насиља деведесетих година прошлог века."

Истовремено сам открио да је академик Цвитковић веома вешт полемичар, што је демонстрирао и у “спору око социологије православља”: "Добро знајући, и као искусан емпиријски социолог, да православље захтева одређене и јасне посебности у проучавању, он у тексту 'Certain Methodological Problems in a Sociological Research of the Orthodox Creed' (Cvitković 2011b: 55-67) ${ }^{28}$ даје читав низ конкретних препорука у ту сврху. Тиме се, можда и не знајући за њу, прикључује оштрој полемици коју је Сергеј Флере ("Questioning the Need for a Special Methodology for the Study of Eastern Orthodohy”, 2008), познати словеначки социолог религије, повео са Миклошом Томком (“Is Conventional Sociology of Religion Able to Deal with Differences between Eastern and Western European Developments?” 2006), исто тако знаним мађарским религиологом, у Social Compass, водећем европском часопису за социологију религије. Но повишеним тоном (“Je li moguća sociologija pravoslavlja”,

\footnotetext{
${ }^{25}$ У АНУБиХ води Одбор за социолошке науке.

${ }^{26}$ Константин Велики је рођен у Наисусу (Нишу) и родни град достојно прославља годишњицу Едикта. Свој предговор и приређену књигу Цвитковићевих радова посвећујем том јубилеју.

27 "Нема веће неслоге од оне која настаје због религије” (Cvitković 2011a: 11).

${ }^{28}$ Касније објављеном и на хрватском (Cvitković 2012: 241-261).
} 
2011c) реагује на чланке два млада социолога религије - на текстове Владана Станковића (2010) "Проблеми заснивања социологије православља" 29 и Ларисе Астахове (2010) "Православна социологија или социологија православља: о могућностима конфесионалне социологије” - који несмотрено отварају већ одавно затворену расправу о могућности конфесионалне социологије, било да је она православна, католичка или протестантска. Том сам затварању, уз помоћ Мануела Х. Мехида (Mejido) (2004: 23-44), и са̂м допринео још 2007. у предговору за књигу Муке са светим: изазови социологије религије. Да, и у томе се слажем са Цвитковићем, социологија религије је јединствена наука и нема потребе за конфесионалним изданцима, али социологија православља - као и она католичанства, протестантизма и, што да не, ислама - регуларна је академска дисциплина у смислу засебног предмета који се може предавати и већ се предаје на многим универзитетима.

\section{Закључак}

Сматрам, колико год то било претенциозно с моје стране, да је академик Иван Цвитковић, међу осталим, допринео социологији религије као:

1. Утемељитељ социологије религије на Универзитету у Сарајеву као засебне социолошке дисциплине, а потом и неких других дисциплина из области религије: религије и конфликти, религија и политика, социологија обреда. Уџбеник Социологија религије служи не само студентима Универзитета у Сарајеву већ и студентима Филозофског факултета у Новом Саду и Нишу и на Високој школи струковних студија за васпитаче у Алексинцу. Такође, уџбеник Религије сувременог свијета служи студентима Универзитета у Сарајеву, Тузли и Бихаћу. Он је тиме дао голем принос образовно-одгојној делатности, ширењу спознаје о религијским различитостима и односу према њима.

2. Оснивач и вођа интердисциплинарног постдипломског студија (“Религијске студије” Универзитета у Сарајеву, заједно са Универзитетима у Аризони и Ослу), што му је омогућило рад на подизању знанственог подмлатка, у БиХ и региону, из области религиологије.

3. Проносилац дијалога и толеранције између хришћана и муслимана. То су следбеници двеју најприсутнијих религија не само у БиХ већ и у Европи и свету (припада им око 55\% светске популације

\footnotetext{
${ }^{29}$ Видети доста спретан Станковићев одговор у чланку “'Odgovor na neka od pitanja prof. Cvitkovića u prošlom broju časopisa Diskursi (1/2011)” (2011: 211-214).
} 
која се изјашњава као верничка). Његови су радови (и наставно ангажовање), особито радови настали након распада Југославије и крвавих ратова 90-их година на подручју некадашње нам заједничке државе, оцењени као допринос ширењу културе дијалога, разумевања и међусобног уважавања. Сви Цвитковићеви текстови говоре у прилог тези о капацитету религија за изградњу мира, али и о њиховом потенцијалу за насиље. Шта ће превладати, зависи од људи који их следе, а не од тих религија.

4. Научник који се са задовољством залагао и залаже за научну сарадњу међу социолозима из држава насталих распадом Југославије, а и из свих балканских земаља.

5. Професор Цвитковић, писац низа капиталних студија из религиологије, посебно из социологије религије, од којих су неке биле изистински бестселери на нашим просторима - како сам већ у неколико наврата написао у рецензијама његових монографија - осим што свагда показује ученост, акрибичност и стилску увежбаност, видно испољава и изврсну обавештеност у стварима социологије религије и политологије религије, богословља и доктринарног наука већине данашњих светских религија, чинећи синтезу големог домета - квалитет који умногоме мањка друштвеним теоретичарима који су се бавили или баве сложеним и контроверзним односом религије и политике. Зато је могао да се упусти, што је у нас реткост, а овде новост, и у анализу односа религије и избора, религије и сиромаштва, религије и политике насиља, политике исмејавања религије и контроверзи око светогрђа. Све је то скоро увек без зазора показивао и на друштвено-историјској ситуацији Босне и Херцеговине, поглавито се осврћући на предратно, ратно и послератно време. Засебно истичем његову отворену, бритку и интелектуално истинољубиву критику опседнутости верских заједница комунизмом (и његовог доприноса развоју атеизма) те положаја атеизма у политици и пракси постсоцијалистичких друштава.

6. Он се потврдио као редак припадник интелигенције који је остао веран својим знанственим, етичким и политичким принципима.

In summa, др Иван Цвитковић, академик АНУБиХ, умировљени редовни професор Универзитета у Сарајеву, истакнути је социолог религије и истински хуманиста. 


\section{Литература}

Abazović, Dino (2010), Religija u tranziciji: eseji o religijskom i političkom, Rabic, Sarajevo.

Астахова, Лариса (2010), Православна социологија или социологија православља: о могућностима конфесионалне социологије. У: Д. Б. Ђорђевић - М. Јовановић (прир.) Могућности и домети социјалног учења православља и православне цркве, Фондација Конрад Аденауер / ЈУНИР, Београд / Ниш, стр. 155-168.

Буквић, Димитрије (2019), Драгољуб Б. Ђорђевић као теоријски (и практични) кафанолог. У: Д. Тодоровић (прир.) Бити соииолог: споменица Драгољуба Б. Ђорђевића, Прометеј / Машински факултет, Нови Сад / Ниш, стр. 85-96.

Vlaisavljević, Ugo (2003), Lepoglava i univerzitet. Ogledi iz političke epistemologije, Centar za interdesciplinarne postdiplomske studije Univerziteta, Sarajevo.

Гавриловић, Данијела - Ђорђевић, Драгољуб Б. (прир.) (2005), Религија у вртлозима глобализације, ЈУНИР / Свен, Ниш.

Делић, Марко (2019), Аутономија књижевног дела - литерарна мерила Томаса Ајсхојера, Православље, 15. децембар, стр. 28-30.

Ђорђевић, Драгољуб Б. (1985), Национално и религијско на селу, Свеске, год. 3, бр. 9 , стр. 216-220.

Đorđević, Dragoljub B. (1990), O religiji i ateizmu. Prilozi sociologiji religije, Gradina / Stručna knjiga, Niš / Beograd.

Ђорђевић, Драгољуб Б. (1991), Поводом енциклопедистике и речничке књижевности о религији, Nissa, бр. 3-4, стр. 526-528.

Ђорђевић, Драгољуб Б. (2007a), Скица за портрет YU социолога религије: Иван Цвитковић (1945-) - социолог религије свестраног видика, Годишњак за социологију, год. 3, бр. 3, стр. 17-28.

Ђорђевић, Драгољуб Б. (2007б), Муке са светим: изазови социологије религије, Нишки културни центар, Ниш.

Ђорђевић, Драгољуб Б. (2008), Иван Цвитковић. У: Узорници и пријани: скице за портрет YU социолога религије, Чигоја штампа, Београд, стр. 103-112.

Đorđević, Dragoljub B. (2013), Encountering Others - Academician Ivan Cvitković, Sociologist of Religion and Humanist. U: I. Cvitković Encountering Others, Yugoslav Society for the Scientific Study of Religion, Niš, str. VII-XIX.

Зриншчак, Синиша (2008), Пледоаје за социологију религије - скица за разговор. У: Д. Б. Ђорђевић Узорници и пријани: скице за портрет YU социолога религије, Чигоја штампа, Београд, стр. 9-14.

Mejido, Manuel J. (2004), On the Genesis and Transformations of Social Compass, Social Compass, god. 51, br. 1, str. 23-44.

Социолошки речник (2007), Завод за уџбенике, Београд.

Stanković, Vladan (2011), Odgovor na neka od pitanja prof. Cvitkovića u prošlom broju časopisa Diskursi (1/2011), Diskursi, god. 1, br. 2, str. 211-214.

Станковић, Владимир (2010), Проблеми заснивања социологије православља. У: Д. Б. Ђорђевић - М. Јовановић (прир.) Могућности и домети социјалног учења православља и православне цркве, Фондација Конрад Аденауер / ЈУНИР, Београд / Ниш, стр. 125-132.

Тодоровић, Драган (прир.) (2019), Бити соииолог: споменица Драгољуба Б. Борђевића, Прометеј / Машински факултет, Нови Сад / Ниш. 
Doprinos akademika Ivana Cvitkovića razvoju sociologije religije (Povodom 75. godišnjice života)

Tomka, Miklos (2006), Is Conventional Sociology of Religion Able to Deal with Differences between Eastern and Western European Developments?, Social Compass, Vol. 53, No. 2 , str. 251-265.

Flere, Sergej (2008), Questioning the Need for a Special Methodology for the Study of Eastern Orthodohy, Social Compass, Vol. 55, No. 1, str. 84-100.

Cvitković, Ivan (1980a), Bilješke o religiji, Oslobođenje, Sarajevo.

Cvitković, Ivan (1980b), Marksistička misao i religija, Svjetlost, Sarajevo.

Cvitković, Ivan (1982), SKJ i religija, Radnička štampa, Beograd.

Cvitković, Ivan (1983), Religija: pitanja i odgovori, Centar za društvene djelatnosti RK SSOBiH, Sarajevo.

Цвитковић, Иван (1986а), Читање традиције: верска штампа и њен однос према културној и религијској свести у нас, Градина, год. 21, бр. 1-2, стр. 105-109.

Cvitković, Ivan (1986b), Tko je bio A. Stepinac, Oslobođenje, Sarajevo.

Cvitković, Ivan (1991a) Rječnik religijskih pojmova, samostalno izdanje, Sarajevo.

Цвитковић, Иван (1991б), Развијати социологију религије, Градина, год. 26, бр. 5-6, стр. 217-224.

Цвитковић, Иван (1991в), Православни међу католицима и припадницима ислама у Босни и Херцеговини, Nissa, год. 20, бр. 3-4, стр. 327-346.

Cvitković, Ivan (1997), Nacija i konfesija u ratu (na primjeru rata u BiH 1991-1995). U: Etno-religijski odnosi na Balkanu, JUNIR, Niš, str. 45-56.

Cvitković, Ivan (2001), Odnos religijskih učenja prema narodu-naciji (sociološki model). U: D. B. Đorđević (prir.) Učenje, organizacija i delovanje verskih zajednica i pokreta, JUNIR / Zograf, Niš, str. 62-66.

Цвитковић, Иван (2002), Однос између националног и конфесионалног идентитета. У: Љ. Митровић - Д. Б. Ђорђевић - Д. Тодоровић (прир.) Културни и етнички идентитети у процесу глобализације и регионализације Балкана, ЈУНИР / Пунта, Ниш, стр. 123-126.

Cvitković, Ivan (2003), Notes on Romas’ Religious Beliefs. U: D. B. Đorđević (ur.) Roma Religious Culture, YSSSR, Niš, str. 27-30.

Cvitković, Ivan (2004a), Sociologija religije (treće izdanje), DES, Sarajevo.

Cvitković, Ivan (2004b), Konfesija u ratu, Svjetlo riječi, Sarajevo.

Cvitković, Ivan (2004v), Relations Between Christians and Muslims (The Case of Balkans). U: D. Todorović (ur.) Evangelization, Conversion, Proselytism, YSSSR / KSE / Punta, Niš, str. 33-39.

Cvitković, Ivan (2005), Rječnik religijskih pojmova, drugo dopunjeno i prošireno izdanje, DES, Sarajevo.

Cvitković, Ivan (2005a), Religije suvremenog svijeta, DES, Sarajevo.

Cvitković, Ivan (2005b), Theme: Religion and Globalization. U: D. Gavrilović (ur.) Religion and Globalization, YSSSR / Sven, Niš, str. 17-25.

Cvitković, Ivan (2006), The Relationship of "Historical Based" Religious Communities Towards Protestant Communities. U: T. Branković - D. B. Đorđević (ur.) Protestantism on the Balkans in the Past, Today and the Future, YSSSR / FME / Punta, Niš, str. 51-59.

Cvitković, Ivan (2007a), Sociologija religije (četvrto izdanje), DES, Sarajevo.

Cvitković, Ivan (2007b), Socijalna naučavanja o religijama, Nacionalna i univerzitetska biblioteka $\mathrm{BiH}$, Sarajevo.

Цвитковић, Иван (2007в), Муке са светим на примјеру данских карикатура. У: Д. Б. Ђорђевић (прир.) Муке са светим, Нишки културни центар, Ниш, стр. 185-195. 
Цвитковић, Иван (2009), Речник религијских појмова, Прометеј, Нови Сад, 482 стр.

Cvitković, Ivan (2011a), Moj susjed musliman, Školska knjiga, Zagreb.

Cvitković, Ivan (2011b), Certain Methodological Problems in a Sociological Research of the Orthodox Creed. U: Orthodox From an Empirical Perspective, YSSSR / IPhST, Niš / Belgrade, str. 55-67.

Cvitković, Ivan (2011c), Je li moguća sociologija pravoslavlja, Diskursi, god. 1, br. 1, str. 260-265.

Cvitković, Ivan (2012), Sociološki pogledi na naciju i religiju II, CEIR, Sarajevo.

Cvitković, Ivan (2013), Encountering Others, Yugoslav Society for the Scientific Study of Religion, Niš.

Cvitković, Ivan (2014), Sociologija obreda, Nacionalna i univerzitetska biblioteka BiH, Sarajevo.

Cvitković, Ivan (2016), Religija u zrcalu teorija, Centar za empirijska istraživanja religije, Sarajevo.

Cvitković, Ivan (2019), Religija u raljama politike, ANUBiH, Sarajevo. 